\title{
Embracing the ROFO Principle before Implementing Lean Production: A Chief Operating Officer's Experiences and Reflections
}

\author{
DOI: 10.12776/QIP.V19I2.621
}

Ah Bee Goh, Nopasit Chakpitak

Received 02 October 2015, Accepted 09 November 2015, Published 31 December 2015

\begin{abstract}
Purpose: The purpose of this paper is to highlight to CEOs (chief executive officers) that implementing the continuous improvement $(\mathrm{CI})$ program requires a gradual overhaul of the entire organization. Nurturing the right working mindset is more important than hastily implementing the CI program to reap the benefits. A right working mindset can be achieved through the ROFO principle. This paper illustrates how Schaffner Thailand (ST) uses the ROFO principle to: i) coach the workers to develop the right working mindset and ii) implement Lean Production (LP) in the entire organization

Methodology/Approach: This case study was carried out solely in ST company. It explains how the company coaches its employees to embrace ROFO principle in a systematic manner. A random sample of about 180 employees was taken to determine if there was a significant change in working mindset before and after the coaching of the ROFO principle.
\end{abstract}

Findings: There was a significant and positive mindset change after the coaching of the ROFO principle. Workers realize that the more they embrace the ROFO principle the better is the learning and the cooperative environment. LP was successfully implemented throughout the whole organization. LP continues to thrive in ST.

Originality/Value of paper: The first author originated the ROFO principle. It is both a management concept and tool. It is easily understood and is not a complex model. A great benefit of it is that it can be applied immediately to generate workforce commitment.

Category: Case study

Keywords: ROFO; Learning; Lean Production; Ownership; mindset 


\section{INTRODUCTION}

In today's competitive world, organizations unceasingly institute continuous improvement programs to stay ahead of their competitors. Continuous improvement (CI) programs such as Total Quality Management (TQM), Six Sigma, and Lean Production (LP) have been pursued aggressively by organizations to improve their business results. Despite the extensive application of the aforesaid tools (or management concepts), many have been unsuccessful (Katz, 1993; Nwabueze, 2001; New, 2007; Näslund, 2013).

Staats and Upton (2011) state that Lean Production (= Toyota Production System (TPS)) can be argued as one of the most vital inventions in manufacturing operations after Henry Ford's manufacturing model for producing the T-model but attempts to implement it have proved to be disappointingly difficult. Näslund (2013) states that a survey on Lean Production by Industry Week reveals that only 2 percent attained their expected goals whereas 74 percent did not make satisfactory progress. On the other hand, there are reports that companies which successfully have implemented continuous improvement programs have achieved substantial savings (Hendricks and Singhal, 1997; Womack and Jones, 1996). There is, however, no doubt that top management of most organizations are keen on implementing CI programs, given the attractiveness of the potential savings. The good questions to any organization before implementation are: 1 . Is the organization ready to implement CI programs? and 2. Will the organization be successful with the implementation?

However, few top managers realize that instituting CI programs like Lean Production and TQM require a total overhaul of the organization. Some researchers advocate that having the right organizational culture is vital to the success of CI programs (Dahlgaard and Dahlgaard-Park, 2006; Lagrosen, 2003; Green, 2012; Ingelsson, Erikson and Lilja, 2012). The research conducted by Dahlgaard-Park et al. (2013) also found that organizational culture has become increasingly more important within the quality management area as indicated by the number of culture related research articles has expanded tremendously especially after the year 2007 .

There is no dispute that having the right organizational culture is important. However, it is the authors' experience that changing the culture of an organization can be extremely difficult, and hence an easier approach is simply to nurture the right working mindset by coaching the employees to take ownership and executing daily tasks well. Daily tasks could mean fixing a broken tap or correcting a work instruction in the assembly process. If simple daily tasks cannot be managed well how can a gigantic task like LP be implemented effectively?

By practicing the ROFO principle employees take ownership to complete daily tasks on-time. In the process, this creates a learning and cooperative environment, which is the most vital step for any organization to achieve before embarking on a CI program. The authors call that the foundation stage and it is a 
serious gap if top managers are not able or willing to recognize the importance of that stage. Top management, in their eagerness to reap short time tangible benefits, has often a tendency to choose embarking on CI programs in an aggressive manner. This is a serious mistake and will mostly result into failures.

This paper presents a case study which illustrates how Schaffner Thailand (ST) has used the ROFO principle to coach employees to develop the right working mindset before implementing Lean Production (LP) in the entire organization.

\section{SCHAFFNER THAILAND (ST)}

ST is the subsidiary of the Schaffner Group which is headquartered in Luterbach, Switzerland. The Schaffner Group is a global leader in the development and production of solutions that ensure the efficient and reliable operation of power electronic systems. ST has two divisions, EMC (Electronic Magnetic Compatibility) and Automotive, and each division manufactures its own family of products (Table 1).

\section{Table - 1 profile of Schaffner Thailand Company}

\begin{tabular}{|l|l|}
\hline Location & Northern Region Industrial Estate, Lamphun 51000, Thailand \\
\hline When founded & 1989 and started with 50 employees only \\
\hline No of managers & More than 30 \\
\hline No of engineers & More than 60 \\
\hline Other professionals & About 20 \\
\hline No of production workers & 1300 \\
\hline Schaffner Group revenue & Swiss Company with about 200 million USD sales. \\
\hline Certifications & $\begin{array}{l}\text { ISO 9000 (Quality Management System standard), ISO 14000 } \\
\text { (Environmental Standard), TS 16949 (Automobile standard), } \\
\text { OHSAS 18001(Safety standard). }\end{array}$ \\
\hline Awards & $\begin{array}{l}\text { In 2014, ST received 2 national awards: "An Outstanding } \\
\text { Establishment in Skill Development" and "The National } \\
\text { Award for Outstanding Corporate in Occupational Safety, } \\
\text { Health and Working Environment" by the Thailand Ministry of } \\
\text { Labor }\end{array}$ \\
\hline EMC products & $\begin{array}{l}\text { Electronic filters for energy efficiency/ reliability. Components } \\
\text { are deployed in energy-efficient drives systems and electronic } \\
\text { motor controls and in machine tools and robotics etc. }\end{array}$ \\
\hline Automotive products & $\begin{array}{l}\text { Components for keyless entry systems as well as solutions for } \\
\text { the drive systems of hybrid and electric vehicles. }\end{array}$ \\
\hline Lean Production & $\begin{array}{l}\text { Started Lean production in late 2008. Today, Lean Production } \\
\text { has been successfully implemented in the entire company. }\end{array}$ \\
\hline $\begin{array}{l}\text { Quality Improvement tools } \\
\text { used }\end{array}$ & $\begin{array}{l}\text { SPC, DOE, Fishbone diagrams, 5 Why analysis, FMEA, } \\
\text { ANOVA and BSC. }\end{array}$ \\
\hline $\begin{array}{l}\text { ROFO principle } \\
\text { implementation }\end{array}$ & $\begin{array}{l}\text { Started ROFO implementation in late 2007 and hence the } \\
\text { company has more than 7 years of practicing ROFO. }\end{array}$ \\
\hline $\begin{array}{l}\text { Legend: ANOVA- Analysis } \\
\text { experiments, FMEA- failure } \\
\text { United States Dollar }\end{array}$ & $\begin{array}{l}\text { mode effect analysis, SPC- statistical process control, USD- } \\
\text { ofiance, BSC- balanced score card, DOE- design of }\end{array}$ \\
\hline
\end{tabular}




\section{LITERATURE REVIEW}

Ohno (1998), who was the founder of Toyota Production System (TPS), and early western pioneers (Womack, Jones and Roos, 1990; Womack and Jones (1996)) coined TPS as Lean Production (LP). Toyota's development and use of TPS to gain competitive advantage against its competitors was so successful that it overtook GM's lead as the world's largest producer of automobiles in 2008. Ohno, famous for listing the seven kinds of wastes, also cautions that simply adopting TPS without a thorough understanding of elimination of waste is meaningless. For example, an employee may appear busy by walking from one place to another but this is not necessarily work. Every employee movement can be sub-divided into two categories, either work or waste (Ohno 1998, pages 54$60)$.

In 1977, Sugimori et al. presented a paper which highlighted two vital elements of TPS: Just-in-time production and respect-for-human system. The paper did not catch high attention of the western world (New, 2007) and some quality experts even added that western organizations are still unable to apply TPS as successfully as Toyota (Spear, 2004, Spear and Bowen, 1999).

Spear and Bowen (1999) researched that the success of Toyota was related to the following four 'hows':

1) How people work

2) How people connect

3) How the production line is constructed

4) How to improve

Liker (2004) presented 14 principles of TPS and readers were advised to study them carefully to get a better understanding on TPS. The research work by Liker (2004), Spear and Bowen (1996), Womack, Jones and Roos (1990) have shed light on the TPS which many western companies still have great difficulty to understand fully.

The first author of this article, who worked with several Japanese companies, has the following supplementary experiences about Japanese employees:

1) Japanese employees are masters of details and documentation, and every step of the production process is well understood by the employees. This is mostly not the case when comparing with western employees.

2) Japanese employees exhibit great discipline in their behaviour.

3) Respect and co-operation among Japanese employees is at such a high level that it is seldom matched in most western companies. 
4) Japanese employees have a strong appetite for learning.

5) During problem solving sessions they accept contradicting views before reaching consensus. In the west, it is often experienced that contradicting views end up in ugly situations but seldom in Japanese companies.

6) Japanese employees normally execute tasks successfully and on-time.

Bhasin and Burcher (2006), in their study on lean failures, propose that for LP implementation to become successful companies must be able to: 1) treat LP as a philosophy, 2) use the LP tools and methods well, and 3) transform the organizational culture.

\section{WAY OF COACHING WORKERS TO EMBRACE THE ROFO PRINCIPLE}

Schaffner Thailand develops its own training protocol called Schaffner Manufacturing Systems (SMS). Under SMS there are modules of best practices that are developed in-house, based mainly on the knowledge and experiences of staff. Schaffer's employees are encouraged to read widely, attend relevant seminars and visit other factories to gain insights into new and innovative practices. SMS is continuously improved by incorporating new ideas, methods and suggestions from employees and external sources. Based on their positive attitudes and good track records three engineers were selected to be trained extensively to become SMS leaders (coaches). SMS leaders are not full-time trainers as coaching is an additional responsibility they have on their shoulders.

SMS modules are tailored to the needs of the company. Some module examples are shown below.

1) $\mathrm{ROFO}$ principle

2) $5 \mathrm{~S}$

3) Lean Production

4) SPC (Statistical Process Control)

5) Five Why analysis

6) What constitutes an effective quality system?

7) Profiles of an effective leader.

It is mandatory for every employee to attend the first three modules (ROFO, 5S \& Lean Production). The COO (Chief Operating Officer) personally coached his top team, middle managers, and SMS leaders including engineers and other professionals. The SMS leaders trained the front-line production workers. The 
trainers use an interactive approach, story-telling, games and brainstorming in the coaching sessions. Below are some of the highlights of the first three mandatory training modules (ROFO, 5S \& Lean Production).

\subsection{ROFO principle (Goh 2001, 2015)}

The ROFO principle teaches employees to take full ownership of the entire process until the final result is delivered. The "entire process" - production or service - is a system of interrelated activities which deliver the final outcome. In such a system workers may occasionally experience problems, failures or defects for which they do not hold the primary responsibility for. Though the primary responsibility lies with another party, the ROFO principle expects that workers who first identify or experience the problem to rectify the issue to the best of their ability and also to prevent any reoccurrences. For example, after the issue has been resolved the worker who holds primary responsibility will be contacted and politely informed of the situation. Preventative measures would then be discussed together to ensure that similar situations would not arise once more. Preventative measure may also include steps taken to improve the quality management system.

Based on this example the ROFO principle expects that each employee in the system has to expand beyond his/her responsibility by reaching out to others whenever needed. We can say that the ROFO principle expects that each individual offers his/her assistance as though he/she owns the entire process (see Fig. 1). The strength of the ROFO model lies in the fact that an environment conducive for team learning is established; in which individuals are able to continually practice and nurture essential skills.

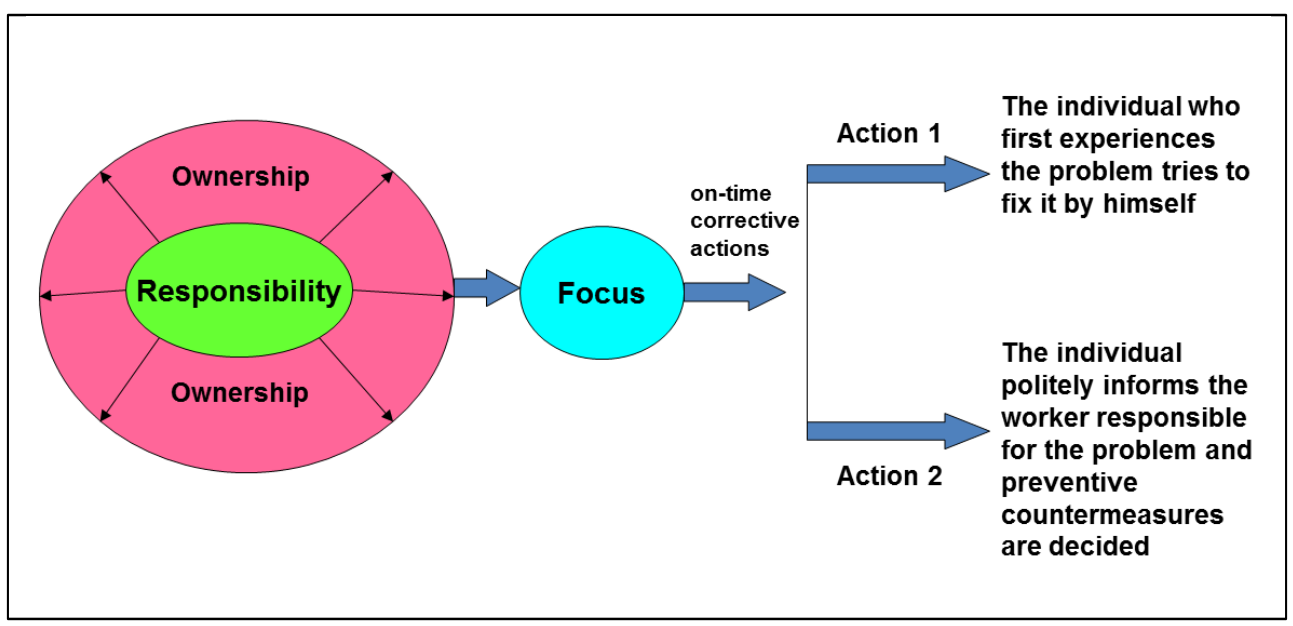

Figure 1 - ROFO principle (Goh, 2015)

Coaching of the ROFO principle is enriched by storytelling, brainstorming sessions and case studies of ROFO leaders of the world. 
The ROFO leaders commonly cited are:

- Nelson Mandela (1918-2013), the first President of South Africa, an antiapartheid fighter who fought for freedom and equal rights for his people.

- Lee Kuan Yew, the former prime minister of Singapore, who is highly respected by Singaporeans as father of Singapore and also for his untiring efforts and commitment in transforming Singapore into a modern nation, comparable to any developed country in the world. Every Singaporean owes him a "thank you" for his immeasurable contributions to the country.

- Admiral Horatio Nelson (1758-1805), a national hero of Britain, famous for his victories during the Napoleonic Wars. His moving phrase, "England expects that every man will do his duty" is fondly remembered.

\subsection{The 5S}

ST employees begin training on the following five basic principles of 5S.

1) Seiri (sort): This is the first step to classify items into "necessary "and "unnecessary" categories. Those that are not necessary are discarded.

2) Seiton (set in order): The second step is to ensure those necessary items are marked and stored in their right places. Everything has its place and every place has its thing.

3) Seiso (Scrub): The third step is to clean the workplace thoroughly.

4) Seiketsu (Standardize): The fourth step is to treat it as a standard for all to adhere to.

5) Shisuke (Sustain): The last step is to ensure that discipline is required by all employees to comply with the standards set.

At each training session, employees are required to take pictures of ST factory on good and bad examples of 5S. In so doing, employees learn wholeheartedly the agreed areas to be improved. It is important to drill them into thinking that the factory should be as clean and orderly as their homes.

The 5S cycle repeats itself and is continuously improved with ideas from employees. In ST, it is said that any colour in the factory is accepted as long as it is "white". The walls and ceilings are hence painted white.

It was not easy to tell the staff to paint the walls white because they argued that it would be difficult to maintain as any dirt or dark patches would be seen clearly. The first author replied that it was exactly what he wanted as any dirty area should be exposed instantly. The same applies to production workers who wear white uniforms. 
Coaching is enhanced by using such real-life examples. $5 \mathrm{~S}$ begins from and ends at toilet and canteen. Inability to keep the toilets and canteen hygienically clean would indicate that managers are not keen in the well-being of their workers.

\subsection{Lean production}

Basically, employees are taught about the removal of the seven types of waste: 1. Over Production, 2. Over Processing, 3. In-efficient transportation, 4. Unnecessary Stock, 5. Unnecessary motions, 6. Waiting times, 7. Rejects and Defects.

Over production is not only the greatest culprit in generating waste but also increases inventory to hide other types of waste. We can say that the level of inventory is as good as the level of water in the sea. High inventory level will hide other types of waste (Ohno 1998, page 59). What is important is to have the right level of inventory to serve customers' needs.

Lego games are used to simulate the differences in output between traditional batch production and one-piece flow. Participants could sense the superiority of lean cell with one-piece flow over the traditional batch production. In short, the principles of lean production (Womack and Jones $(1996,2003))$ are:

1) Specify value by specific product seen from the customers' points of view,

2) Identify the value stream for each product,

3) Make the value flow without interruptions by eliminating wasteful steps,

4) Pull system: Let the customer pull value from the producer,

5) Pursue perfection.

It is an absolute requirement for all employees to be trained in the above 3 modules. Employees who have undergone the first round of training will continue for their second round when their turn is due. Coaching is a non-stop process and employees who attend the second round or more will receive a higher content of knowledge. No two training sessions are exactly alike as the objective is to have fun and develop a climate conducive to learning. Employees who have been with the company between 3 and 6 years would have undergone at least two coaching sessions.

After the SMS training, ST management institutes a series of management methods or performance measures to encourage employees to embrace the ROFO principle. It is not possible to discuss all of them in detail in this paper and only a few key areas will be highlighted as shown below. 


\subsection{Daily production meetings}

Two production meetings are held daily, one in the morning at 10 am and the other in the evening at $5 \mathrm{pm}$. The morning meeting is to show the delivery plan for the day, and the evening meeting is to confirm whether they have delivered in accordance to the morning plan.

Immediate corrective measures will be triggered for any deviation to the plan. The primary purpose of the daily production meetings is to ensure that all shipments are met in accordance to the planned customer demands. In ST, nothing is more important than meeting customer deliveries. To show this commitment, the management has officially made it a rule that no one (including the managing director) has the power to stop or cancel the meeting. It was often experienced that Chief Executive Officers (CEOs) when confronted with more pressing issues would take the easy way out to cancel the production meeting.

The COO and his top team attend the meetings daily, and the meetings are chaired by the production manager. Obstacles (can be quality or human resources related) that could threaten customer deliveries are brought up in the daily meetings. All issues are being presented at the meetings and decisions are made and implemented swiftly. Each meeting starts on-time and no meeting is allowed to last more than 30 minutes. If the meeting takes more than 30 minutes then participants are entitled to walk out. Why this rule?

If the ROFO principle is practiced fully, participants will present their version of "solutions" during the meetings and not problems for an agreed solution. Imagine, if everyone comes with a problem, the meeting will last for hours without fruitful results. Another benefit of this rule is that it forces the chairman to hold the meeting in a constructive way. Before implementation of the ROFO principle, production meetings usually took between 45 and 90 minutes. Today, the average duration is about 20 minutes.

\subsection{Daily walk: Go to the workplace (Genba) to observe}

The managing director (MD) walks to the factory at least 5 times a day and constantly searches for potential areas of improvement. There was an incident which happened in August 2007, when the MD was at the shop floor with his staff and he realized that employees were extremely busy. People were pushing the trolleys of parts from one location to another and others were carrying parts to the assembly lines. There was a lot of walking but people did not walk for nothing as each was trying to do his/ her part well.

The MD immediately coached his staff that those busy people were not productive as there were unnecessary transportation and walking. The MD remarked further that it was entirely the fault of management. Today it is the habit of managers and engineers to walk to the shop floor a few times a day to learn what can be further improved. They walk to each lean cell to observe the visual control board (Liker principle 12, 2004, Spear 2004) which is a real-time 
monitoring control board of the activities in the lean cell. Managers and engineers would always ask themselves and the workers: "What can go wrong?" and "Is this the best way to work?"

Learning to observe is critical as in the words of the famous football coach, Alex Ferguson (Elberse and Ferguson, 2013): "Observation is critical to management. The ability to see things is key - or, more specifically, the ability to see things which you don't expect to see".

\subsection{Weekly administration meeting}

This is a general meeting which has no fixed agenda. Everyone can attend and can bring up any issue for discussion. The objective of this meeting is not only to listen to the staff but also to share ideas openly. All participants are considered equal regardless of rank and function. It is a dialogue and discussion meeting where views from participants are expressed without fear. All ideas are noted and if feasible will be considered for implementation. The weekly administration meeting, which starts at 10:45 am and ends at 12:00 pm, is chaired by the MD.

\subsection{Monthly operations meeting}

The MD chairs this meeting where the purpose is to track the progress on the following first level key process indicators (KPIs):

1) Production efficiency,

2) Inventory turnover,

3) On-time delivery to customers,

4) Number of employees trained on the ROFO principle,

5) Direct and indirect Labor hourly rate,

6) Purchase Price Variance,

7) Quality at first-passed yield (FPY),

8) Statistical Process Control (SPC) implementation,

9) Number of Lean cells implemented or improved.

For each KPI, an owner will present actual figures versus the target, and any deviation from the target will have to be explained by a five WHY analysis. Everyone has to use an official template of a five WHY analysis and it is through this form of standardization that time is saved in the interpretation and fruitful exchanges are ensured. The first meeting started in 2007, and until to date not a single meeting has been missed.

In the five WHY presentation, participants have to explain their problems clearly, the root causes from their observations and scientific experiments, and finally the 
countermeasures. The key is to present scientific facts and not simply general opinions. Few realize that a proper five WHY analysis gives rise not only to single loop but also to double loop learning (Argyris, 1999; Senge, 1994).

\subsection{Communication, recognition and rewards}

Effective communication involves a two-way process, but only few companies have managed to achieve this two-way process. Why? Firstly, workers do not express their thoughts because of fear that their supervisors may not agree with them. Secondly, employees have the impression that ideas brought up by them, regardless of how beneficial they potentially are, will never be implemented.

Management has eliminated the fear factor by stating that there is no penalization for making statements that may not turn out to be correct. It is a golden rule that no one is allowed to reprimand or blame employees who have made mistakes. Employees make mistakes mostly because of lack of support from managers and engineers. Leaders should create an environment where no one is afraid to speak out. More importantly, all levels of staff should be able to voice their opinions and this is what the management group wishes to achieve. Managers are constantly reminded that they must listen attentively to their subordinates' views. They should seek to understand before seeking to be heard.

There is no need for official appointments as one can always walk into another's office for a discussion. The MD's office is always open and it is common to see scores of staff going in and out of his office. For LP to be successful, CEOs must clearly state their objective of linking LP implementation with the company's strategy. Failure to do so has various consequences, some of which would pose serious hindrances to the LP program. The MD takes great efforts to explain to all his employees the objective of the ROFO principle and its link to pride, learning and the LP program.

Many CEOs communicate matters which are highly relevant to the future of the company only to their key staff but not the entire workforce. The MD makes it a point to communicate issues that will impact the future of the company to all his 1,300 employees. Conversations between managers and staff typically involve phrases such as, "we want to win and beat our competitors through sheer, honourable effort. We have the ROFO spirit etc." The phrase, "We have the ROFO spirit" is articulated and rearticulated in daily meetings, emails, and other formal meetings as well as in informal gatherings. Research conducted by Neeley and Leonardi (2011) revealed that effective managers always say the same thing twice or more.

Management believes that to achieve a ROFO organization, its reward and recognition system has to be improved. One major criterion for annual salary increment and promotion is to practice the ROFO spirit. The MD and his top managers constantly scout for employees who behave "ROFO-fully". To illustrate a real example: 
A computer aided design engineer had been very helpful to her colleagues. She worked through late hours to finish drawings for urgent projects. She was approachable and always delivered results on promise. She was constantly picked up by her colleagues as a model of ROFO behavior. It caught the attention of the management and eventually she was groomed, developed and promoted to division manager with a quantum increase in her compensation package. This example is not the only one as many local Thais have been promoted to fill senior positions which were once held by foreign expatriate managers. In this manner, the dividing line between rewarding ROFO and non-ROFO employees has become crystal clear. True ROFO people are outstanding employees, and outstanding employees must be paid outstandingly. Besides compensation packages, ST managers are also aware that employees want to be heard and recognised; therefore every presentation about their achievements or findings, if requested by employees, will be entertained, regardless of rank.

The above coaching, meetings and other related CI activities went on for about one year before the first prototype lean cell was installed in 2008. The cell was built with full participation of the production people. It was a cell used as a guinea pig for managers, engineers and production people to observe and to learn. Management was in no hurry to add further cells unless employees were convinced of LP benefits. Numerous improvements were made from building one cell to another. Today, ST has more than 60 cells and it took 6 years to reach this stage. It was a gradual transformation to LP.

\section{AN EXAMPLE OF LP IMPLEMENTATION}

In this example a product (codenamed product $\mathrm{K}$ ) was selected for LP implementation. Top management realized that cost reduction for product $\mathrm{K}$ was necessary because it was not generating the expected profit. Product K's ability to compete in the market would be weakened seriously if nothing was done. As a result of LP implementation two lean improvements were carried out, and as a consequence product $\mathrm{K}$ not only became more profitable but it also gained market share from competitors. Table 2 summarizes all the achieved results.

One significant milestone achieved was that the first passed yield (FPY) improved from $67 \%$ to $99.5 \%$. For illustration purpose only to explain the FPY of $67 \%$, the authors use a simple three - station assembly process to complete the finished product. Imagine the first, second, and third stations have yields of $98 \%$, $96 \%$ and $71 \%$ respectively. The FPY is the product of the three station yields which is $67 \%(0.98 \times 0.96 \times 0.71=0.67)$. This means if 100 units are to be assembled at station one, only 67 good units are achieved after station three and the remaining 33 units $(100-67=33)$ will have to be reworked. 
Table 2 - Comparison of the results of two Lean Improvements on Product $K$

\begin{tabular}{|l|c|c|c|}
\hline \multicolumn{1}{|c|}{ Item } & Traditional Line & $\begin{array}{c}\text { Improvement1 } \\
\text { Assembly Lean Cell }\end{array}$ & $\begin{array}{c}\text { Improvement2 } \\
\text { Coupled Lean Cell }\end{array}$ \\
\hline $\begin{array}{l}\text { Efficiency } \\
(\%)\end{array}$ & $61 \%$ & $92 \%$ & $105 \%$ \\
\hline $\begin{array}{l}\text { Working Area } \\
\text { Square metre }\left(\mathrm{m}^{2}\right)\end{array}$ & $150 \mathrm{~m}^{2}$ & $100 \mathrm{~m}^{2}$ & $75 \mathrm{~m}^{2}$ \\
\hline $\begin{array}{l}\text { Travelling Part } \\
\text { metre (m) }\end{array}$ & $500 \mathrm{~m}$ & $160 \mathrm{~m}$ & $135 \mathrm{~m}$ \\
\hline $\begin{array}{l}\text { Manpower } \\
\text { (Persons) }\end{array}$ & 18 & 13 & 1.5 \\
\hline $\begin{array}{l}\text { Throughput } \\
\text { (Days) }\end{array}$ & 13 & 6 & $18 \mathrm{X}$ \\
\hline $\begin{array}{l}\text { Waiting Time } \\
\text { (Days) }\end{array}$ & $70 \mathrm{X}$ & $30 \mathrm{X}$ & 30 \\
\hline $\begin{array}{l}\text { Cycle Time } \\
\text { coded units }(\mathrm{X})\end{array}$ & 18 & 27 & $99.5 \%$ \\
\hline $\begin{array}{l}\text { Units per Hour } \\
\text { (UPH) }\end{array}$ & $67 \%$ & $88 \%$ & \\
\hline $\begin{array}{l}\text { First Passed Yield } \\
\text { (FPY) } \\
(\%)\end{array}$ & & 5 & \\
\hline
\end{tabular}

Note: Efficiency= standard time divided by actual time. FPY= product of all the station yields, for example, Y1, Y2 and Y3 represent the yields of stations 1, 2 and 3 correspondingly. FPY = Y1xY2xY3.

\section{MEASURING MINDSET CHANGES METHODOLOGY /RESULTS}

A questionnaire survey was carried out in the company in the last quarter of 2013 to assess whether there had been a mindset change before (period I: July 2002 to June 2007) and after implementation of the ROFO principle (period II: July 2007 to June 2012). The questionnaire was sent to 180 randomly selected employees from five different categories of staff (see appendix I), and 129 employees completed and returned the questionnaire.

The selected respondents were asked to judge the result of 14 different daily tasks before and after ROFO implementation by selecting one of the following result classifications:
A- Very little progress.
B- Executed halfway.
C- Executed successfully but took longer time than necessary.
D- Executed successfully and on-time. 
The selected respondents were also requested to decide positions " 1 " or "2" for all listed D results as indicated below:

1. Required constant follow up and special actions by superiors.

2. Required no special actions/ supervision by superiors.

The classifications of $\mathrm{A}, \mathrm{B}, \mathrm{C}$ and $\mathrm{D}$ were scored as 2.5, 5.0, 7.5 and 10 respectively.

The following hypotheses were formulated:

H0: There are no significant changes in employees' mindset between periods I and II.

H1: There are significant changes in employees' mindset between periods I and II.

H2: There are no significant differences in opinions between category 1 (top management) and category 5 (front- line or production workers) in period I.

H3: There are no significant differences in opinions between categories 1 and 5 in period II.

Paired t-test was used to test hypotheses $\mathrm{H} 0$ and $\mathrm{H} 1$. For hypotheses $\mathrm{H} 2$ and $\mathrm{H} 3$, two- sample testing was applied.

The results are shown in Tables 3 and 4 .

Table 3 - Results of all categories

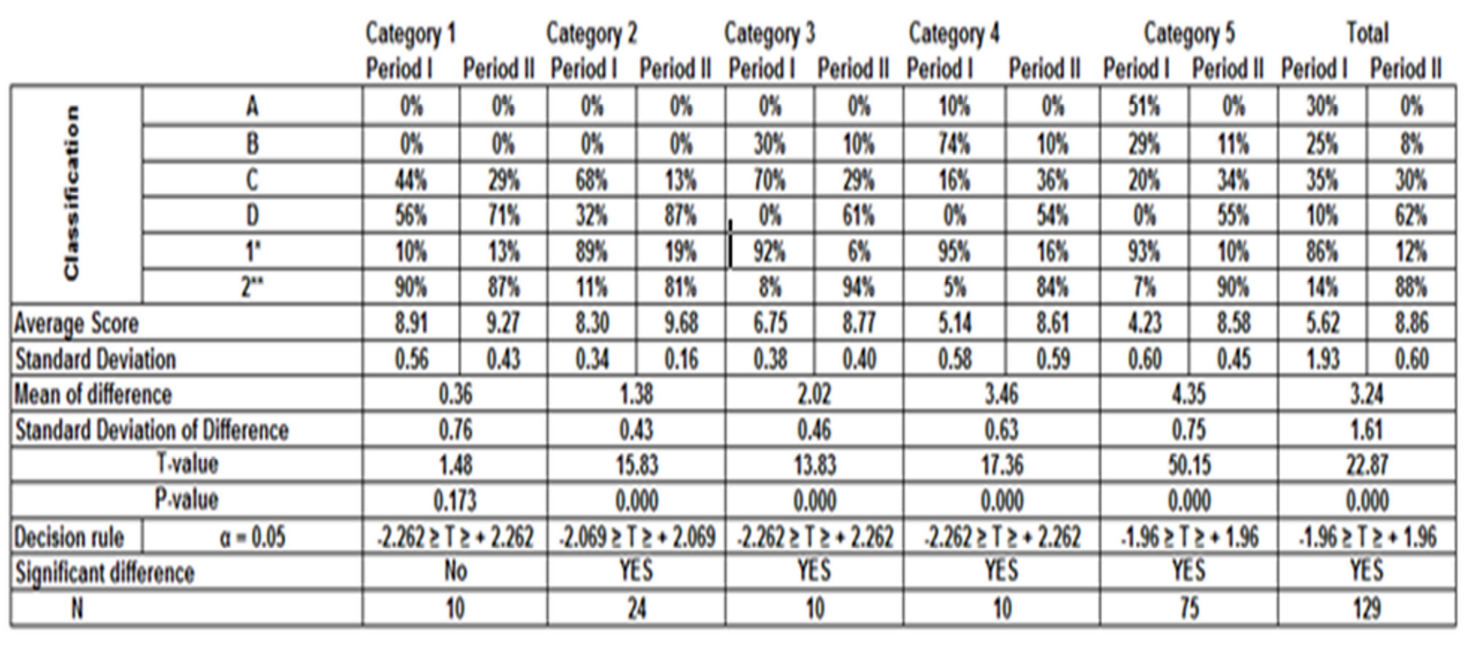


Table 4 - Results between categories $1 \& 5$ only

Period I

Period II

Category 1 Category 5 Category 1 Category 5

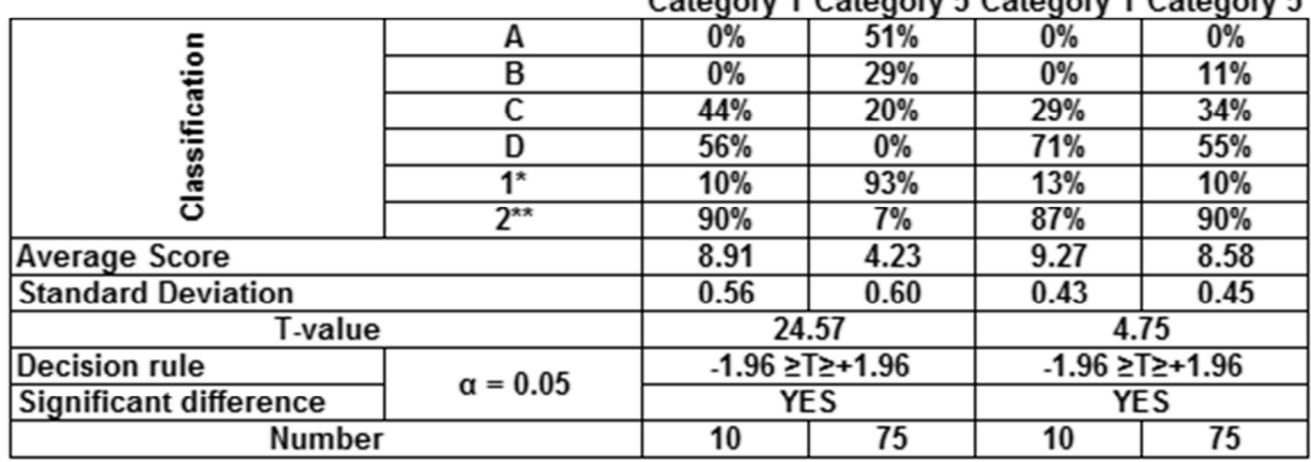

$1^{\star}$ - Required supervision and special action

$2^{\star \star}$ - No special action required

\section{DISCUSSION}

In Table 3, the statistical tests show that there has been a significant change in staff's mindset for all staff categories except for category 1 (top managers). The biggest change is seen in category 5 (Front line or production workers such as assemblers and packers etc.) where the average score improved from 4.23 to 8.58. The smallest change is seen in category 1 (top managers) because this group of respondents already had a very high average score (8.91) before implementation of ROFO. Although the small change in score from 8.91 to 9.27 was not statistical significant, there was still an improvement. The results in Table 3 ( under the Total column) confirm that the right mindset has been successfully nurtured and developed, and therefore hypothesis H1 is supported by the data.

Table 4 shows that there is a significant difference in opinion between categories 1 (top managers) and 5 (front line, production workers, packagers etc.) in period I as well as period II, which means that both hypotheses (H2 and H3) could not be supported. However we can see that the degree of difference in opinions between those two staff categories has been reduced drastically as demonstrated by the Tvalue (4.75) in period II.

Analyzing Tables 3 and 4 further reveals the following:

- In period I, the lower the category of staff, the poorer is the perception that daily tasks are executed well. This finding is interesting as top and bottom levels of staff do not share the same perception.

- Categories 1 and 2 have registered a zero percentage for classifications A and B but not categories 3, 4 and 5. Lower categories of staff feel that the execution of daily tasks is slow or poor but this feeling is not perceived by upper categories of staff ( $1 \& 2$ ). Why? This is because upper categories 
of staff know that if daily tasks are not executed well their company would be in trouble. They correct it by using extreme supervision, and maybe so much that the feeling of poor daily task execution is lost compared to the feeling of lower categories of staff. This is confirmed by the survey results (categories 3, $4 \& 5$ ) that at least $92 \%$ of daily tasks require supervision and special actions.

- In period II, the average score for all categories of staff ranges from 8.58 to 9.68 , indicating a significant improvement in positive mindset.

Having the right mindset gave rise to right behavior as demonstrated by the employees that embarked on the two lean improvements on product K. The employees loved the working environment which was co-operative and also conducive to learning. In this sense, the ROFO principle unites employees to work towards the common good of the company.

\section{REFLECTIONS / CONCLUSIONS}

Dahlgaard, Pettersen and Dahlgaard-Park (2011) in their work on lean health care said that employees may accept poor quality as long as it is not their responsibility when things go wrong. This is an unhealthy mindset, and they propose their '4P Leadership Model' (Leadership, People, Partnership, Processes and Products) as a foundation for attaining organizational excellence. Their 4P Leadership Model starts by "building quality into people" which is the foundation for building quality into Partnership, Processes and Products.

In short it is all about people issues and that is the reason why the company started the implementation of LP by first developing the right mindset through the ROFO principle. Management concentrated on building the right foundation (right working mindset) before installing the first lean cell, and they did not insist on more LP cells to be added unless employees were fully convinced of their benefits. Having the right mindset leads to the right behavior as demonstrated by the employees that embarked on the two lean improvements on product K. The employees loved the working environment which was co-operative and also conducive to learning. In this sense, the ROFO principle unites employees to work towards the common good of the company.

There is no doubt that effective implementation of LP will result in huge savings and delivery of more and better values for the customers, but achieving it without a deep understanding and respect of human needs will not be sustainable in the long run. To illustrate an example, it is common knowledge that standing workers in a lean cell will show better productivity than sitting workers. The transition from sitting to a standing position was carried out together with a careful study of employees' well-being. As an example, pregnant workers were exempted and soft floor mats were placed for the employees to step on. This is what Sugimoiri et al. (1977) meant to 'respect human systems'. No company can survive with ignoring human needs and unhappy workers. It is the authors' belief 
that one of the factors which has caused LP implementation failures in many companies, is that management often pays lip service to employees' needs.

A mandatory requirement by the Thai government to increase daily wage from 169 Baht to 300 Baht in 2013 did not hurt the company's cost competitiveness. This huge increase of daily employee wages by $78 \%$ had been counteracted by productivity improvements and the ROFO spirit of the people. In 2011 there was a flood crisis and the company managed it so well, thanks to the ROFO spirit, that not even a single customer's delivery was delayed.

This paper has illustrated that nurturing the right working mindset in a systematic manner before implementing LP or other change programs is the right approach, and the authors would like to advise other top managers to adopt such an approach. The ROFO spirit gives rise to an environment conducive for workers to work together, to get things done without much hassle, which in turn gives rise to learning.

\section{ACKNOWLEDGMENTS}

The authors wish to thank Professors Dahlgaard, Jens J. (Linköping University, Sweden), Dahlgaard-Park, Su Mi (Lund University, Sweden), Pattamaporn Khunanukornkul, Rattaphom Khlaiaksorn and Derniese Goh for their help in this paper.

Special Note: The first author is the Chief Operating Officer of ST.

\section{REFERENCES}

Argyris, C., 1999. On Organizational Learning. $2^{\text {nd }}$ edition. Oxford: Blackwell.

Bhasin, S., Burcher, P., 2006. Lean viewed as a Philosophy. Journal of Manufacturing Technology Management, 17(1), pp.56-72.

Dahlgaard, J.J. and Dahlgaard-Park, S.M., 2006. Lean production, six sigma quality, TQM and company culture. The TQM Magazine, 18(3), pp.263-281.

Dahlgaard, J.J., Pettersen, J. and Dahlgaard-Park, S.M., 2011. Quality and lean health care: a system for assessing and improving the health of healthcare organisations. Total Quality Management \& Business Excellence, 22(6), pp.673689.

Dahlgaard-Park, S.M., Chen, C-K., Yang, J-Y. and Dahlgaard, J.J., 2013. Diagnosing and prognosticating the quality movement- a review on the 25 years quality literature (1987-2011). Total quality Management \& Business Excellence, 24(1-2), pp.1-18.

Elberse, A. and Ferguson, A., 2013. Ferguson's formula. Harvard Business Review, October, pp.116-125. 
Goh, A.B., 2001. Disbanding the Quality department in Leica Instruments Singapore- Published in: Singapore Quality Institute Yearbook 2001. First presented at the Quality seminar organized by Singapore Quality Institute in Pan Pacific hotel Singapore, Oct. 2000.

Goh, A.B., 2015. ROFO principle generates ownership, commitment and team learning- mindset change before implementing total quality management. Total Quality management \& Business Excellence, 26(8), pp.854-874.

Green, T.J., 2012. TQM and organizational culture: How do they link?. Total Quality Management \& Business Excellence, 23(2), pp.141-157.

Hendricks, K.B. and Singhal, V.R., 1997. Does implementing an effective TQM program actually improve operating performance? Empirical evidence from firms that have won Quality Awards. Management Science, 43(9), pp.1258-1274.

Ingelsson, P., Erikson, M. and Lilja, J., 2012. Can selecting the right values help TQM implementation? A case study about organizational homogeneity at the Walt Disney Company. Total Quality Management \& Business Excellence, 23(1), pp.1-12.

Katz, A., 1993. Eight TQM pitfalls. Journal of Quality and Participation, 6(4), pp.24-27.

Lagrosen, S., 2003. Exploring the impact of culture on quality management. International Journal of Quality \& Reliability Management, 20(4), pp.473-487.

Liker, J.K., 2004. The Toyota Way. New York, NY: McGraw-Hill.

Näslund, D., 2013. Lean and six- sigma- critical success factors revisited International. Journal of Quality and Service Sciences. 5(1), pp.86-100.

Neeley,T. and Leonardi, P., 2011. Defend Your Research: Effective Managers Say the Same Thing Twice (or More). Harvard Business Review, May 2011, pp.38-40.

New, S.J., 2007. Celebrating the enigma: the continuing puzzle of the Toyota Production System. International Journal of Production Research, 45(16), pp.3545-3554.

Nwabueze, U., 2001. How the mighty have fallen: the naked truth about TQM. Management Auditing Journal, 16(9), pp.504-513.

Ohno, T., 1998. Beyond the Toyota Production System. New York: Large-Scale Production. Productivity Press.

Senge, P.M., 1994. The Fifth Discipline. New York: Currency Doubleday.

Spear, S. and Bowen, H.K., 1999. Decoding the DNA of the Toyota Production System. Harvard Business Review, September- October, pp.96-106.

Spear, S.J., 2004. Learning to Lead at Toyota. Harvard Business Review, May, pp.78-86. 
Staats, B.R. and Upton, D.M., 2011. Lean Knowledge Work. Harvard Business Review, October, pp.100-110.

Sugimori, Y., Kusunoki, K., Cho, F. and Uchikawa, S., 1977. Toyota production system and Kanban system materialization of just-in-time and respect-for-human system. International Journal of Production Research, 15(6), pp.553-564.

Womack, J.P., Jones, D.T. and Roos, D.T., 1990. The Machine that Changed the World. New York: Maxwell MacMillian International.

Womack, J.P. and Jones, D.T., 1996. Beyond Toyota: How to Root Out waste and Pursue Perfection. Harvard Business review, September/October, pp.140146.

Womack, J.P. and Jones, D.T., 1996, 2003. Lean Thinking, New York: Free Press. 


\section{Appendix I}

Survey on mindset change before and after implementing of ROFO principle between period i \& ii (R- Responsibility, O- Ownership, F- Focus, O- On-time corrective action)

1. Name of company

a. Address.

2. Designation.....

3. No of years in company

4. Total no of years of working experience to- date.

5. Kindly tick the category below that is appropriate to you;

a. Category 1-Top managers like Managing Director and those who report directly to the Managing

Director.....

b. Category 2- The Professionals like accountants, mid- level managers and engineers etc.

c. Category 3-Supervisors who supervise the front- line workers.

d. Category 4- The technicians like repairers and maintenance staff etc.....

e. Category 5- The front- line or production workers such as assemblers and packers etc.

6. This question is to gauge whether there is any mindset change in carrying out daily tasks between

Period I - (July 2002 to June 2007) \& Period II - (July 2007 to June 2012)

In our company, the following are normal (no special knowledge required) tasks or actions that have been assigned to the staffs (could be any individual e.g. your peer, your subordinate or team leader or higher level staff etc.). Kindly rate to the best of your knowledge by circling the appropriate letter. In all cases, assume that the deadlines are agreed and accepted.

A- Very little progress.

B- Executed halfway.

C- Executed successfully but takes longer time than necessary.

D- Executed successfully and on- time.

Also for those circled "D-executed successfully and on-time", please fill in the appropriate number in the box as listed below;

1. Requires constant follow up and special actions by superiors without which it will not be successful and on- time.

2. Requires only minimal follow up and no special actions by superiors.

Example; If you circle " $D$ " for item " $a$ - to submit a quality report" and you assess that the program requires constant follow up and special actions by superiors without which it will not be successful and on-time, you will write "l" in the box 


\begin{tabular}{|c|c|c|c|}
\hline & & Period I & Period II \\
\hline a. & To submit a quality report... & $\mathrm{ABCD}$ & $\mathrm{ABCD}$ \\
\hline b. & To develop an itinerary for customer visit.... & $\mathrm{ABCD}$ & $\mathrm{ABCD}$ \\
\hline c. & To clean a dirty floor .................... & $\mathrm{ABCD}$ & $\mathrm{ABCD}$ \\
\hline d. & To sort $100 \%$ the bad parts ........................... & A B CD & $\mathrm{ABCD}$ \\
\hline e. & Deliver 200 products on - time to customers......... & $\mathrm{ABCD}$ & $\mathrm{A} B \mathrm{CD}$ \\
\hline f. & Counsel your staff for bad behavior ................... & $\mathrm{ABCD}$ & $\mathrm{ABCD}$ \\
\hline g. & To prepare a power point presentation for CEO visit & $\mathrm{ABCD}$ & $\mathrm{ABCD}$ \\
\hline h. & To train operators for new products.................. & $\mathrm{ABCD}$ & $\mathrm{ABCD}$ \\
\hline i. & Ensure suppliers will deliver parts on-time ........... & $\mathrm{ABCD}$ & $\mathrm{ABCD}$ \\
\hline j. & Submit a quotation to customer....... & $\mathrm{ABCD}$ & $\mathrm{ABCD}$ \\
\hline k. & Implement a safety program.......................... & $\mathrm{ABCD}$ & A B CD \\
\hline 1. & Fixing a broken tap in a toilet............................ & $\mathrm{ABCD}$ & $\mathrm{ABCD}$ \\
\hline $\mathrm{m}$. & To raise a purchase order ............................. & $\mathrm{ABCD}$ & $\mathrm{ABCD}$ \\
\hline & To follow up with peer on task not completed...... & $\mathrm{ABCD}$ & $\mathrm{ABCD}$ \\
\hline & & & \\
\hline
\end{tabular}

\section{ABOUT AUTHORS}

Ah Bee Goh has Ph.D in Knowledge Management, a Bachelor degree (Honours) in Production Engineering and 3 Masters digress in Industrial Engineering, Business Administration, and Finance (with Distinction). He is a professional engineer and has more than 40 years of working experience in international companies. His interests are in Continuous Improvement programs which incorporate learning, modern manufacturing techniques (Lean, Six Sigma and Quick Response Manufacturing) and quality and reliability engineering. Current position is Chief Operating Officer of Schaffner group of companies, in charge of its global operations.

Nopasit Chakpitak earned his Ph.D from Strathclyde University and had worked 17 years before he joined in 2004 as a Dean of College of Arts, Media and Technology, Chaing Mai University, Thailand. His main research interests are Knowledge Engineering, Artificial Intelligence applications in power industry, and supply chain management. In 2012, he became Dean of International College, Chiang Mai University. Besides his active roles in his daily routines, he supervises doctorate students in Knowledge Management. 